\title{
PRODUCTION, SIZE DISTRIBUTION, AND LENGTH WEIGHT RELATIONSHIP OF LOBSTER LANDED IN THE SOUTH COAST OF YOGYAKARTA, INDONESIA
}

\author{
Aisyah and Setiya Triharyuni \\ Research Center for Capture Fisheries, Ancol-Jakarta \\ Received April 19-2009; Received in revised form May 20-2009; Accepted May 31-2010
}

\begin{abstract}
Lobster is one of the most important fisheries export commodities. An increasing trend of annual production during 1999-2005 was occurred, however a decreasing trend during 2005-2007 was observed. It is likely that the long lived and slow growing species group do not capable to balance the fishing pressure. Information on lobster fisheries were gathered through desk study while field surveys and biological observations were focused in Baron sub district at the largest lobster collector in the district of Gunung Kidul, Yogyakarta. From data analysis it was found that the dominant size of lobster collected in January to October 2009 was in the stage of juvenile or can be categorized as seed with the monthly average of about $52 \%$ of the total catch. It was also identified that lobster species consisted of sand lobster (Panulirus homarus), brown spiny lobster ( $P$. penicillatus), pearl lobster ( $P$. ornatus), dark green striped leg spiny lobster ( $P$. versicolor), painted spiny lobster ( $P$. longipes), grey-blue spotted legs ( $P$. polyphagus), and red Spanish lobster (Scyllarides squammosus). The first two species were the most abundance group as reflected by the highest amount in the catch followed by $P$. ornatus. Lobster fishing season characterized by high production in the south coast of Yogyakarta occur at the end of the year to the beginning of the following year. Some management measures leading to the optimum and sustainable yield of lobster fisheries in the south coast of Yogyakarta include application of minimum legal size and protection of parent stock at the collector level should be introduced.
\end{abstract}

KEYWORDS: $\quad$ lobster, South Coast of Yogyakarta, seeds of lobster

\section{INTRODUCTION}

Lobster is an important marine fisheries commodity in Indonesia, even in other parts of the world, current and future. Percentage of lobster exports compared to production of shrimp in 2006 was about $2.3 \%$. From the year 1999-2006 lobster exports continued to increase, with average of $9.1 \%$, with European Union,
Japan, and the United States as the countrees of destination.

Lobster is an Indonesian important fisheries export commodities, that cover wide market area to all the continents of the world. The largest export destination was the Asian countries as shown on Table 1.

Table 1

Export volume and value of fishery products by continent (2006)

\begin{tabular}{|c|c|c|c|}
\hline No. & Destination & Volume (tonnes) & Proportion (\%) \\
\hline 1 & Asian countries & 3590 & 93.4 \\
\hline 2. & Australia & 85 & 22 \\
\hline 3 & America USA: & 81 & 2.1 \\
\hline 4 & European countries & 90 & 2.3 \\
\hline 5 & Africa & 0.13 & 0.003 \\
\hline & Total & 3,845 & 100.0 \\
\hline
\end{tabular}

Sources: The National Statistic, DGCF (2006)

Lobster production in Indonesia come from all provinces of Indonesia, one of them came from Java, that was about $10.4 \%$ from total production of lobster in Indonesia in the period 1997-2007. The largest proportion come from Sumatra and the lowest is East Nusa Tenggara (Anonymous, 2007). Lobster or barong shrimp or reef prawns also called mangkara, spread in almost all provinces in Indonesia, as the part of tropical waters that characterized by the cluster of coral reefs. Based on the national statistic the production is under the fish production, but the prices are highest, which makes lobster an important commodity compared to others in capture fisheries.

In the world market, there are currently four known lobsters; the true lobster-Homaridae, spiny lobsterPalinuridae, cray fish-Astacidae, and Spanish lobsterScyllaridae. Three types of lobsters, the cray fish, spanish lobster, and spiny lobster are known to be present in Indonesia (Subani, 1981). Four species of

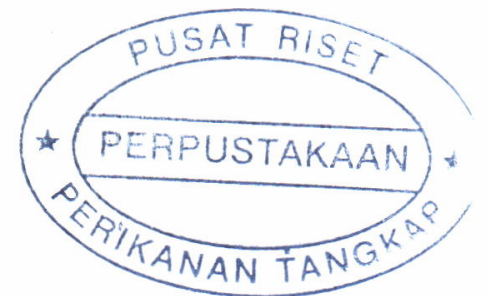


lobster that are internationally harvested on a commercial basis include American lobster (Homarus americanus), European lobster (Homarus gammarus), spiny lobster (Panulirus spp.), and rock lobster (Jasus spp.). Most of lobster groups in Indonesian waters belong to the family Palinuridae, consists of five genera; Justitia, Linuparus, Palinustus, Panulirus, and Puerulus, represented by 19 species including the six genera that commonly represented in Indonesian waters (FAO, 1998).

In Indonesian waters, altogether there are seven recorded species of lobster. These include Panulirus ornatus, $P$. penicillatus, $P$. homarus, $P$. versicolor, $P$. longipes, $P$. Polyphagus, and Scyllarides squammosus (Subani, 1981; Subani, 1983; Moosa \& Aswandy, 1984; Suman et al., 1993; Suman et al., 1994), while the seven recorded lobster species found in different environment according to Romimohtarto \& Juwana (1999) include $P$. homarus, $P$. penicillatus, $P$. longipes, $P$. polyphagus, $P$. versicolor, $P$. Ornatus, and $P$. dasypus. $P$. homarus provide the most dominant species followed by $P$. penicillatus.

Based on their distribution lobster are grouped in different types of habitat (FAO, 1998; Moosa \&
Aswandy, 1984; Kanna, 2006), ie lobster that live in coastal waters and shallow reefs/continental species ( $P$. homarus and $P$. penicillatus), lobster that live in coral waters/coral species ( $P$. longipes and $P$. versicolor, $P$. ornatus, and $P$. femoristriga) and lobster that live in offshore/oceanic species ( $P$. polyphagus).

The ever increasing trend of lobster annual production in Indonesia during 1999-2005 was observed, and a decreasing trend in the following twoyears was occurred (Anonymous, 2007) (Figure 1). From this description, it was likely that lobster exploitation that lead to the decline in population is due to the high market demand. This is related to the biological nature of these species group that are belong to the long lived and slow growing species (Lagler et al., 1977; Subani et al., 1982; Herianti, 1997). As it is known that lobster life cycle and the gradual development in general can be divided into the following stadia; egg stadia (9-12 months), prelarvae (1-1.5 months), larvae (12 days to 1,5 months), it was informed that from post larvae stadia until the complete transformation or reach adult phase will need 5-8 years (www.lobster.um. maine.edu/).

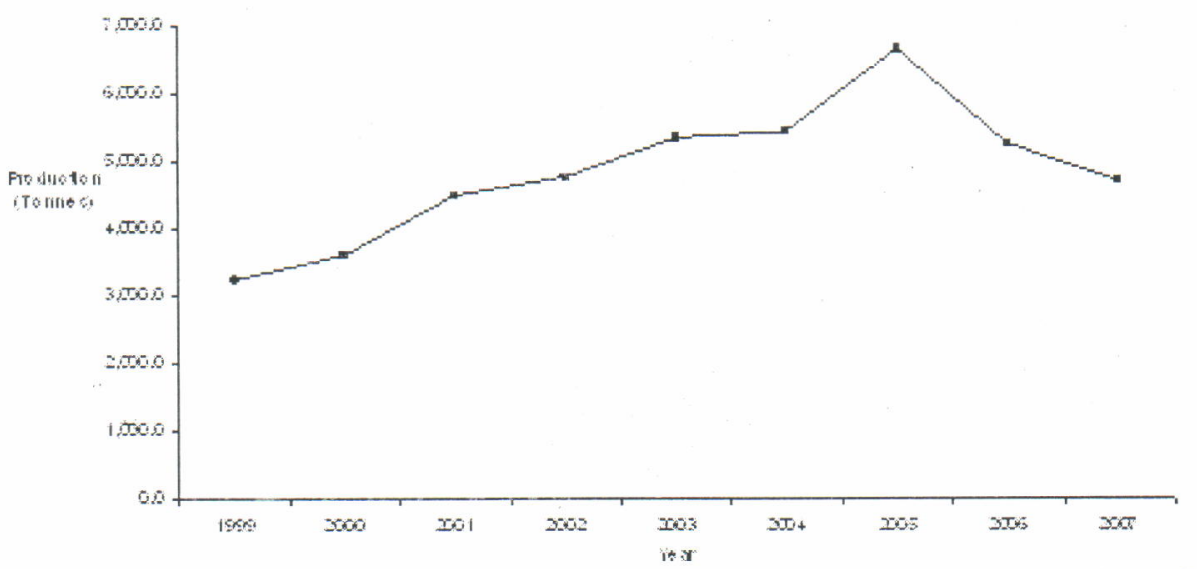

Figure 1.

Annual trend of lobster production of Indonesia.

This study try to elucidate the production, size distribution, and length weight relationship of lobster in relation to the importance of lobster commodity and to manage the resources, due to very limited information avalaible on lobster resources expecially in the South Coast of Yogyakarta.

\section{MATERIALS AND METHODS}

The research was conducted on September and October 2010 in Baron, South Coast of Yogyakarta. The location of sampling site has been chosen based on available information that is one of the quite large lobster fishing area in South Coast of Java beside South Coast of Central and West Java.

In this study, data analyzed were collected from a number of primary and secondary data. Primary data includes biological data such as identification of lobster species and length weight measurement were obtained by sampling at the biggest collector in Baron. Secondary data include reports of lobsters landed in Baron landing site, statistical data from both the Director General of Capture Fisheries and District of Marine Affairs and Fisheries Services of Gunung Kidul, and also notes of lobster collector. 
Species identifications were mainly based on Chan (1998); Moosa \& Aswandy (1984). Carapace length was measured in $\mathrm{cm}$ unit and weight in gram. Carapace length ( $\mathrm{CL}$ or: $\mathrm{Cl}$., distance from the median supra-orbital horns to the median posterior carapace margin); total length (TL, distance from the median supra-orbital horns to the tip of the telson with the abdomen fully extended) (Figure 2). All measurements are in centimetres. Length and weight relationship follow the equation, (Effendi, 2002):
$\mathrm{W}=\mathrm{a} \mathrm{L}^{\mathrm{b}}$

where:

$$
\begin{aligned}
& \mathrm{W}=\text { weight }(\mathrm{g}) \\
& \mathrm{L}=\text { carapace length }(\mathrm{cm}) \\
& \mathrm{a}=\text { intercept } \\
& \mathrm{b}=\text { slope }
\end{aligned}
$$

Others aspects regarding lobster fishery were gathered through observations, interviews, and literature studies.

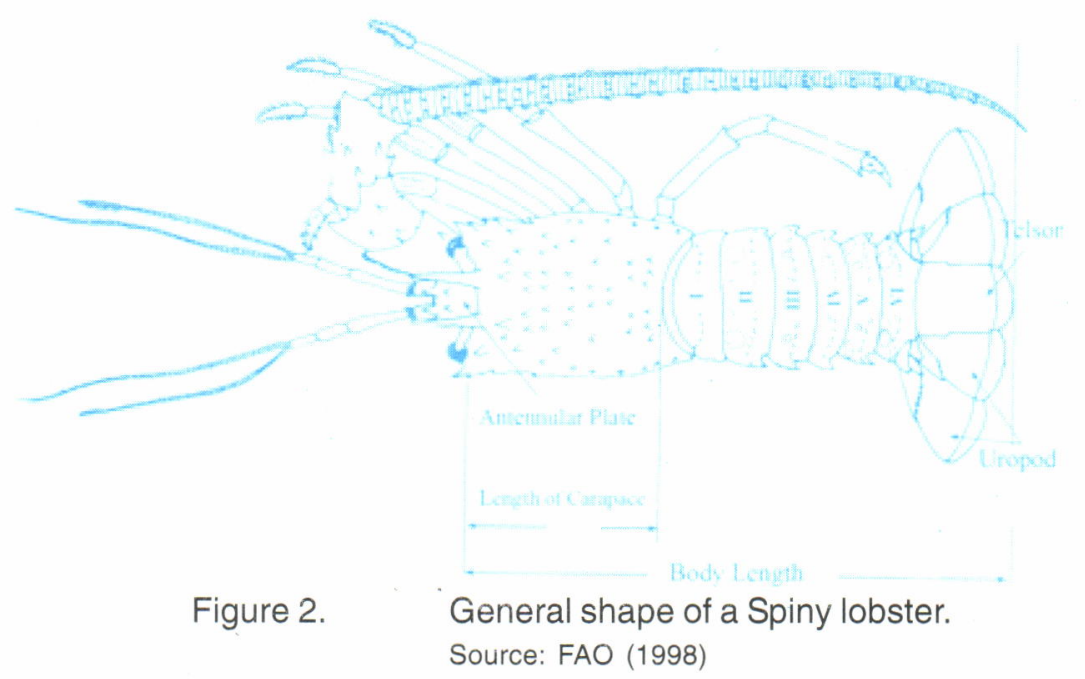

\section{RESULTS AND DISCUSSION}

\section{Lobster fisheries in Yogyakarta}

In Yogyakarta Province, lobsters provide one of the ten most important fisheries production (Anonymous, 2008). Although the contribution in weight was only $3 \%$, but the value reached to about Rp.2.8 billion, almost the same amount obtained from seaweed production that contributed to around 15\% (Table 2). Lobster fishing activities within Yogyakarta Province distributed along the coastal waters of the districts of Gunung Kidul, Bantul, and Kulonprogo, of which Gunung Kidul contribute the most contributor in lobster production in 2008 . The five landing places that function also as the market of lobster in this

\begin{tabular}{|c|c|c|c|}
\hline No. & Items & Volume (tons) & Proportion (\%) \\
\hline 1 & Lobsterifenul us spp & 50.741 & 30 \\
\hline 2 & Jelly fish (Rhooleme spp) & 37506 & 20 \\
\hline 3. & Sea snails (Gastropods) & 102363 & 60 \\
\hline 4. & Seaweeds (Eucheme spp.) & 265500 & 150 \\
\hline 5. & Siver pomfret (Pamous arcenteus) & 62.997 & 4.0 \\
\hline 6. & Rays (Trigonidae) & 85191 & 50 \\
\hline 7. & Skipjack (Ketsuwonus pelamis) & 167.657 & 9.0 \\
\hline 8. & Tuna (Thumus spp) & 273925 & 15.0 \\
\hline 9. & Eastern little tuna (Euthynus spp) & 441.774 & 29.5 \\
\hline 10. & Hairtails (Trohums spp) & 287485 & 16.0 \\
\hline
\end{tabular}
province include Sadeng, Wediombo, Drini, Baron, and Ngrenehan.

Table 2. The ten most important recorded fisheries production in 2007-2008

Lobster species landed in Yogyakarta consisted of six species of the genus Panulirus and one of the genus Scyllarides. The species of the genus Panulirus include Panulirus homarus (sand lobster), Panulirus penicillatus (rock lobster), P. ornatus (pearl lobster), $P$. longipes (painted spiny lobster or white spotted red spiny lobster), P. versicolor (bamboo lobster or dark-green striped leg), and P. polyphagus (grey-blue 
spotted legs) while Scyllarides squammosus (red Spanish lobster) forms the only species of the genus Scyllarides. From landing data it was found that the first four species of Panulirus provide the most dominant that cover almost $99 \%$ of lobster landing.
These include $47 \% P$. homarus, 34\% $P$. penicillatus, $9 \% P$. longipes, and 5\% P. ornatus (Figure 3). The occurrence of Scyllarides squammosus was usually observed during the months of October to December until January next year.
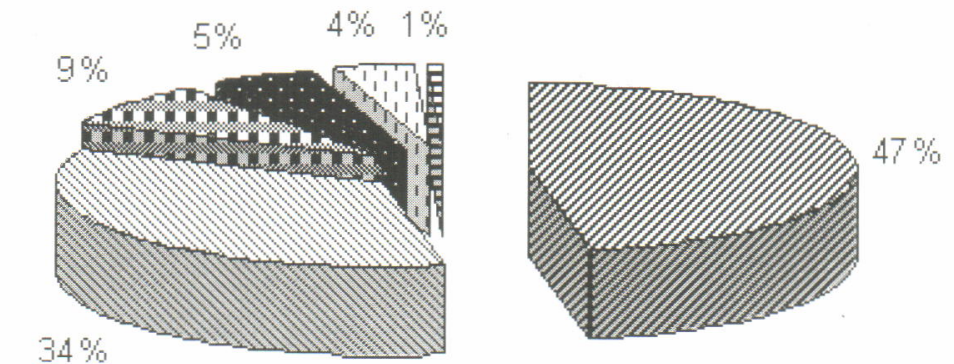
Q P. homarus
Q P. peniciriatus
움 P. longipes
- P. omatus
口. versicolor
- S. soummosus

Figure 3.

Percentage of each type of lobster that collected in Baron.

Suadi et al. (2001) reported that fishermen in the South Coast of Yogyakarta approximately 2000 people. This amount included the trap (locally called krendet) fishermen. Meanwhile, in 2003, it was reported that fishermen Gunung Kidul varied based on regions and season. Gillnet fishermen in Ngrenehan lead to 35-40 people, trap fisherman are about 60100 people. While in 2009, trap fisherman in Baron approximately less than 10 people because of type of this gear is seasonal. This amount could be increase in peak season for example at the end of the year to the beginning of the following year. Statistic of Gunung Kidul District shown that the annual trip was likely decreased. in 2007, the trip was about 104 trips per unit while in 2008 about 77 trips per unit. seasonal characteristic tend to decrease the annual trip due to the low of annual fishing trip.

Fishing gears used to catch lobster are mainly trap (Figure 4a) and monofilament gillnet locally called

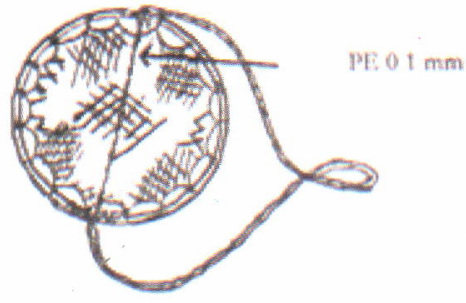

(a) jaring sirang with the principle dimension of 4-6 m depth, 30-40 m length, and of $8-10 \mathrm{~cm}$ mesh size for one piece of gillnet (Figure 4b). Lobster caught by these gear is usually entangle. Krendet is a passive fishing gear placed in the cracks of rocks or in shallow water on rocky shore. The form are vary from round, rectangular to oval. Physically, krendet fishing gear consists of several parts, ie frame, webbing, ropes and bait ropes. In general, the framework made of bamboo, wood, rattan, and iron. Diameter frame size is usually between $80-100 \mathrm{~cm}$. Webbing was made from polyamid with meshsize 1.75-4.5 inch, consist of 1-3 piece. Rope was made form polyethilen, 4-6 $\mathrm{mm}$ diameter, $2 \mathrm{~m}$ long. The diameter of bait rope between 1-2 $\mathrm{mm}$ in length varies according to the diameter of the framework. The catch of lobster usually done in shallow reefs, and some other placed the krendet at the edge of a cliff during a night. Average of daily catch around $0.5-3 \mathrm{~kg}$.

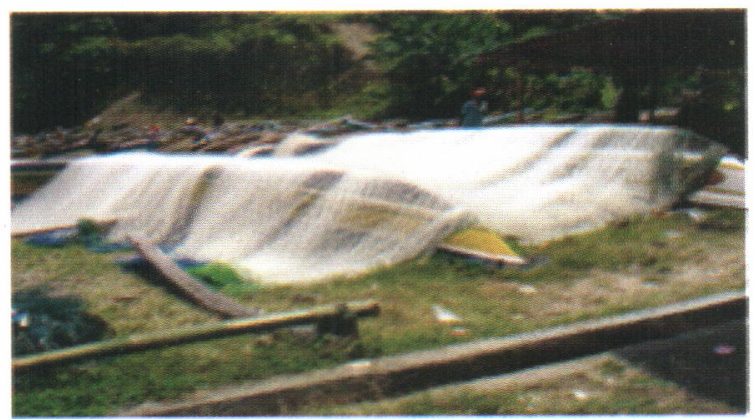

(b)

Figure 4.

Trap (krendet) and jaring sirang. 
According to Wirosaputro (1996), the composition of fish and lobster production recorded in TPI Baron was $5: 1$ (fishes $=83.20 \%$ and lobsters $16.8 \%$ ). There was a tendency of this proportion to change leading to a decreased of lobster proportion in the catches.
Lobster annual production recorded in Baron TPI from 2001-2008 was sharply fluctuated (Figure 5), with the maximum of around 3.37 tons occurred in 2003, that was likely similar to the statistical data of Yogyakarta.

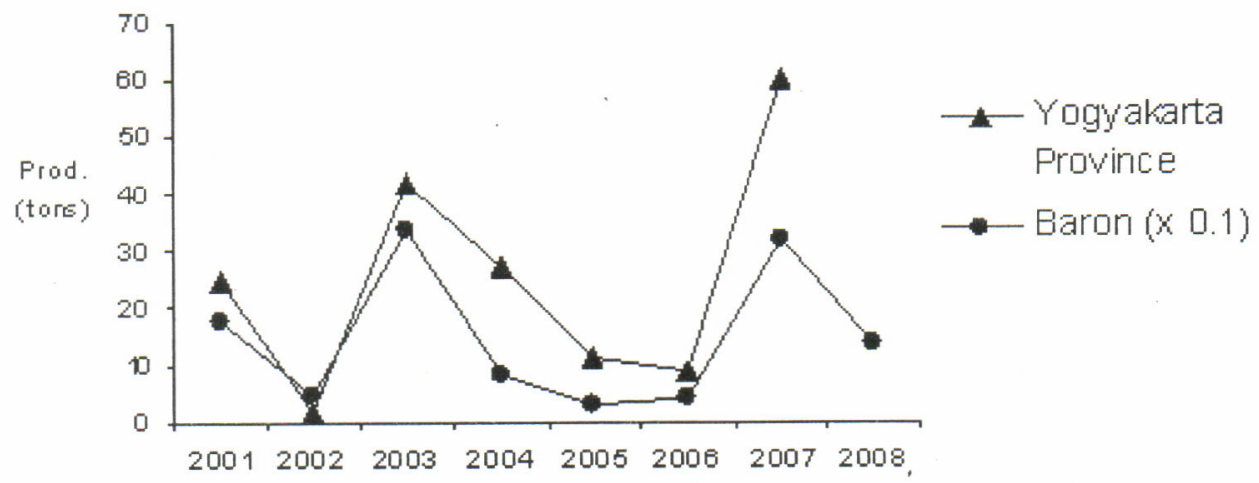

Figure 5. Annual recorded production (tons) of lobster in Baron and Yogyakarta.

Suadi et al. (2001) describes that the fluctuation of trend of catch per unit effort from 1988 to midle of 2000 tend to increase. Meanwhile, by using statistical data (2007-2008) by using krendet data, shown decreasing of catch per unit effort from $2.4-1.6 \mathrm{~kg} /$ trip.

Based on lobster data reported in Baron suggests that in general a lot of lobster caught in the rainy season, which is around November to January or at the end of the year to the beginning of the following year. This situation is similar with lobster fishing season in south coast of Kebumen (Argopeni, Karangduwur, and Pasir landing sites). In general, the highest annual production occured in November or December and the lowest production in August, while the catch in March to July was negligible.

\section{Size Distribution}

From sampling activities carried out in September until October 2009, it was found that the individual size of lobsters range between $4.1-14.1 \mathrm{~cm}$ carapace length or total length of $10.3-34.8 \mathrm{~cm}$, with the range of weight from 30-1,000.2 g. From sampling data analysis it was found that the dominant size of lobster collected in September and October 2009 was in the stage of juvenile or can be categorized as seed (30$100 \mathrm{~g}$ ) average of about $52 \%$ of the total catch. Some berried females were commonly found in the fish markets. This lack of spawner protection could damage reproductive potential of the lobster population that lead to the recruitment failure that resulted in declining lobster population. As reported by Chang et al. (2007) a minimum legal size should be established for the fishery to protect egg production potential of lobster population. Since 1995, concern to catch berried lobster has arisen as they were usually discarded or cheaply sold almost at the same price with the unberried ones. In fact, berried female is very important as seeds supplier for the conservation of natural biological resources of the lobster (Wirosaputro, 1996).

Weight frequency distribution data of 342 specimen of seven species of Panulirus spp. collected by random sampling ranging from $0.03 \mathrm{~kg}(30 \mathrm{~g})$ until $1.03 \mathrm{~kg}$ $(1,030 \mathrm{~g})$ has been available. The 'super grade' (starting from the size of $0.1 \mathrm{~kg} / 100 \mathrm{~g}$ ) was the most expensive. While in the international market, as reported by the FAO-Infofish (Smith, 1995), the lowest grade was 0.45 $\mathrm{kg}(450 \mathrm{~g}$ or equal to $1 \mathrm{lb})$, and the highest grade was $2.25 \mathrm{~kg}(2,250 \mathrm{~g}$ or equal to $5 \mathrm{lbs})$.

Overall samples of six species of lobster was dominated by the size of 100-150 $\mathrm{g}$ (Figures 6 and 7). It is appeared that the dominant size of lobster measured in September and October 2009 was in the stage of juvenile or can be categorized as seed. Badrudin et al. (2005) reported that the size of lobsters caught in July until August 1997 was dominated by the group of $100 \mathrm{~g}$, whereas in the next month (September 1997), the catch was dominated by the group size of $150 \mathrm{~g}$. 


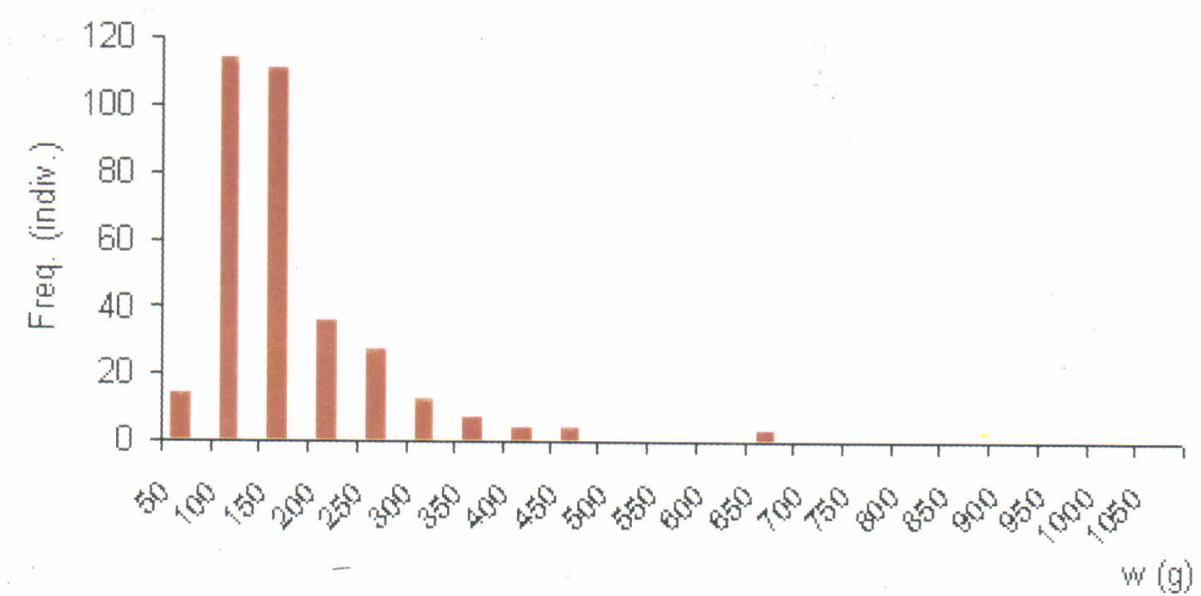

Figure 6. Weight distribution of lobster measured in Baron coast, September and October 2009 $(\mathrm{N}=342)$.

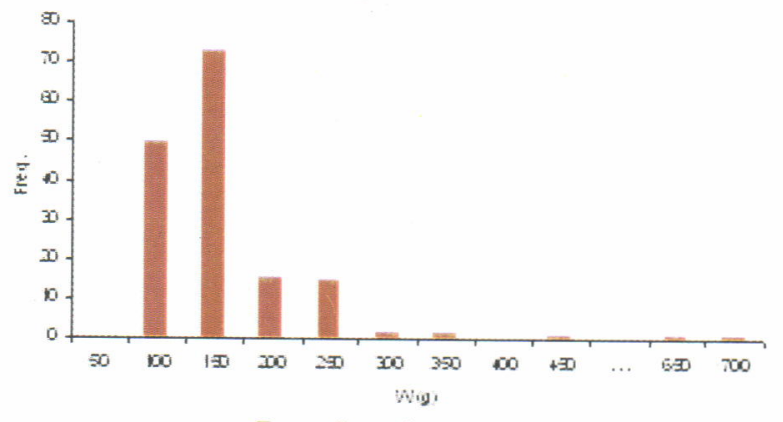

Panulirus homarus

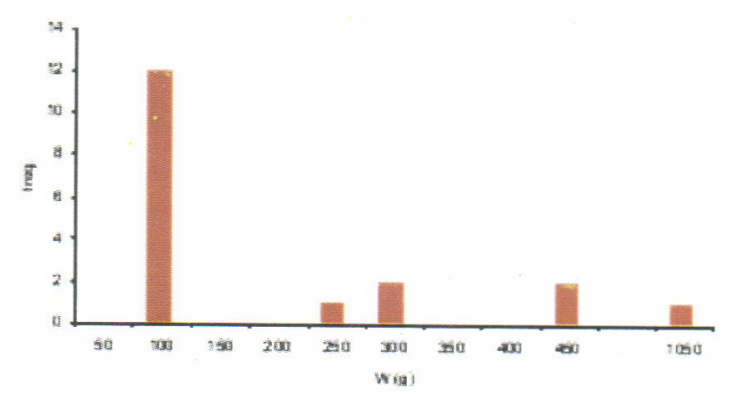

Panulirus ornatus

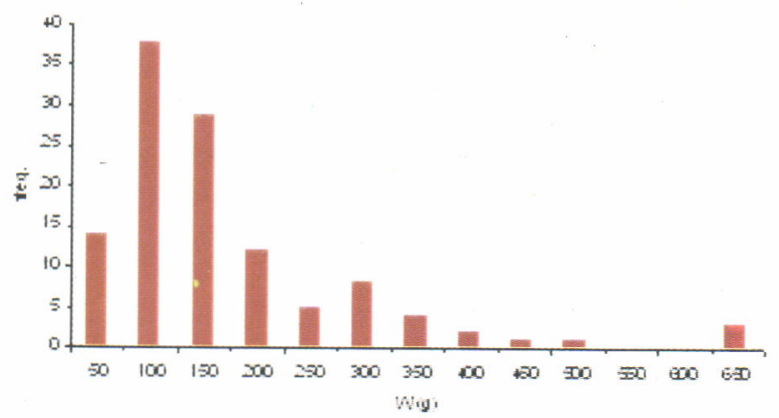

Panulirus penicillatus

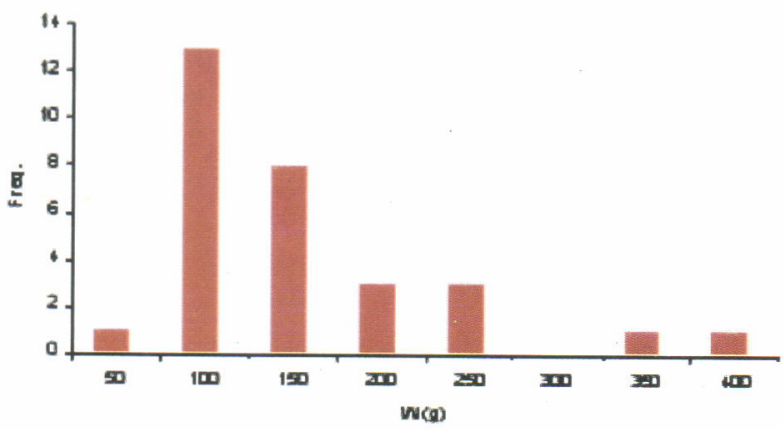

Panulirus longipes

Figure 7. Weight distribution of four species of lobsters.

It was further reported that the size of lobsters in the two last quarter of 1997 in which the size of the dominant group was likely parallel (July/August 100 and $200 \mathrm{~g}$ in September), in the first quarter of 1998 was dominated by the size of $200 \mathrm{~g}$ (Figure 8). 


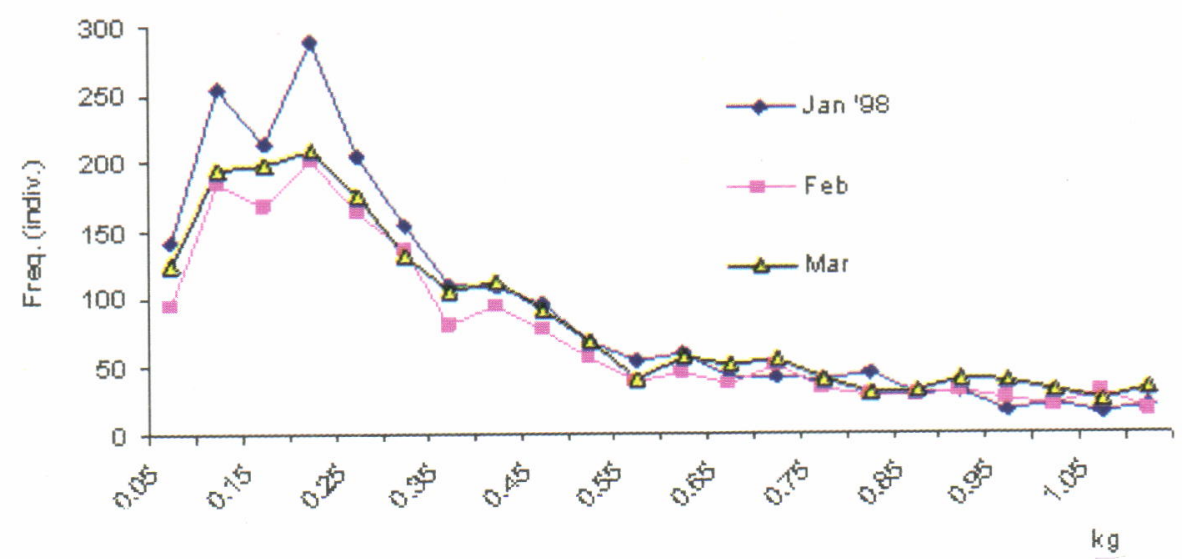

Figure 8. Weight frequency distribution of lobster in January to March 1998 (Yogyakarta). Source: Badrudin et al. (2005)

\section{Length-Weight Relationship}

Length weight relationship of Panulirus spp., based on sample collected from fishers are presented in Table 3. Results of the t-test of the $\mathrm{b}=3$ value for $P$. homarus, $P$. penicilatus, $P$. longipes, $P$. ornatus, and $P$. versicolor was statistically not significant, meaning that the growth pattern of the five species in the south coast of Yogyakarta was isometric. F-test used to determine how the influence of independent variable to the dependent variable. From results the F-test for all species, $F_{\text {value }}$ larger than $F_{\text {table }}\left(F_{\text {value }}>F_{\text {table }}\right)$ this means that the regression models significantly appropriate.

Table 3.

Parameters of length-weight relationship of lobster landed in Baron, September and October 2009

\begin{tabular}{|c|c|c|c|c|c|c|c|c|}
\hline No. & Species & $\mathrm{n}$ & CL Range $(\mathrm{cm})$ & Intercept (a) & Slope (b) & $\mathrm{R}^{2}$ & $F_{v a 1}$ & $\mathrm{~F}_{\mathrm{t} \text { tble }}$ \\
\hline 1. & P. homarus & 161 & $5-10.5$ & 0.630 & 2.788 & 0.95 & 32241 & 39 \\
\hline 2. & P. penchlatus & 117 & 4.6 & 0 & 2.895 & 0.97 & 3388.6 & 39 \\
\hline 3. & P. longipes & 30 & 5. & 0. & 3.006 & 0.93 & 35 & 4.2 \\
\hline 4. & P. ometus & 18 & 5.9 & 0. & 2.996 & 0.98 & 96 & 45 \\
\hline 5 & P. versicolor & $13^{\circ}$ & $63-10.1$ & 0.347 & 3118 & 0.98 & 519.7 & 4.8 \\
\hline
\end{tabular}

Remarks: *) species rarely found

While Suman et al. (1994) reported that the growth pattern of Panulirus homarus in Pangandaran and West Aceh (Suman \& Subani, 1993) was negative allometric. This growth pattern implies that the two species were likely more slender, where growth in length is faster than growth in weight. This is in contrast to the growth of lobsters in the South coast of Bali, that indicates the positive allometric pattern indicating that the lobster is fat or plump. The differences of growth pattern would likely due to higher nutrient level in certain waters that lead to accelerate lobster feeding behavior. 
ไมเ

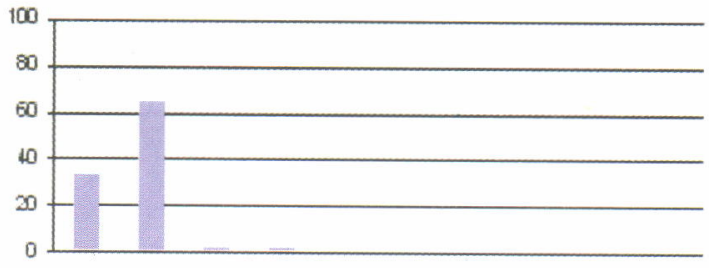

Feb

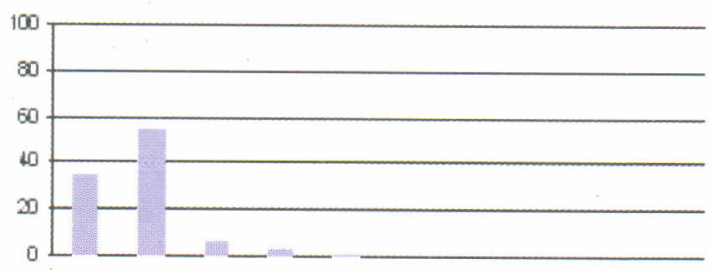

Mar

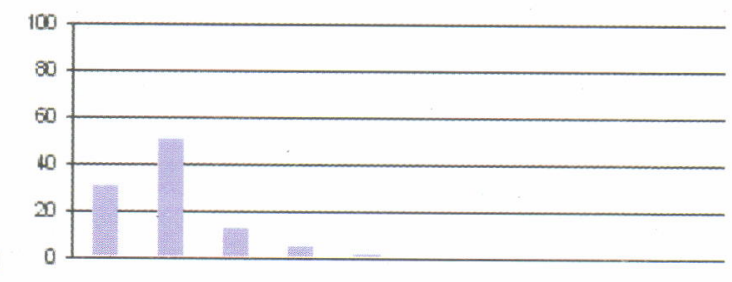

Apr

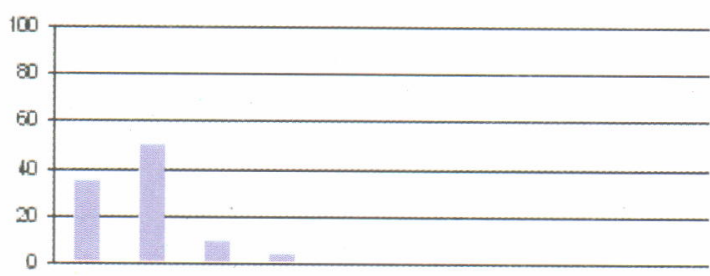

Mesi

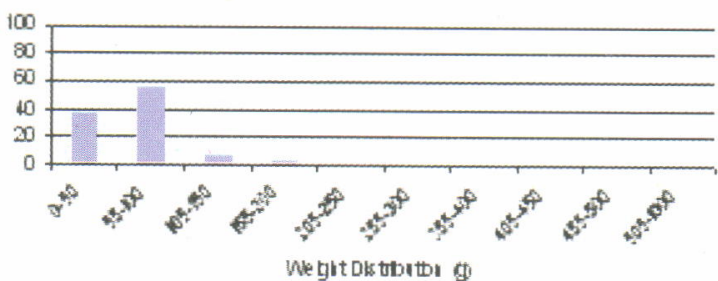

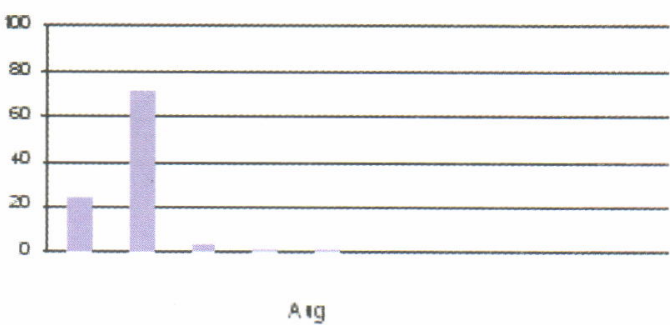
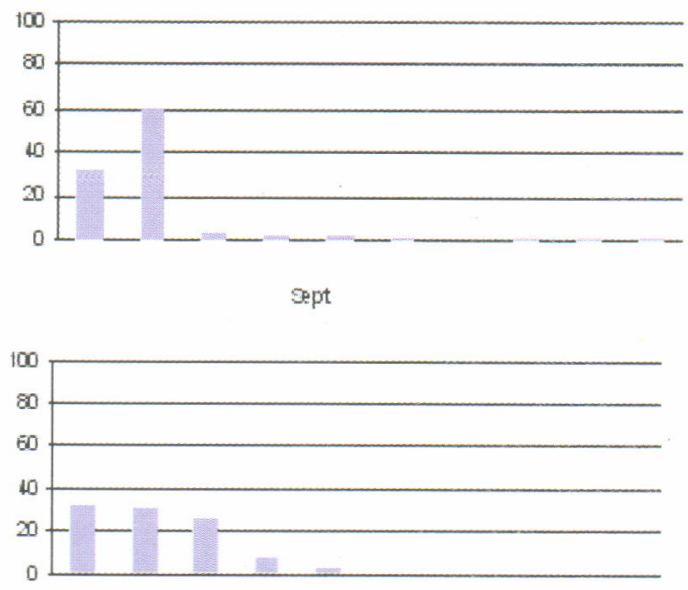

oet

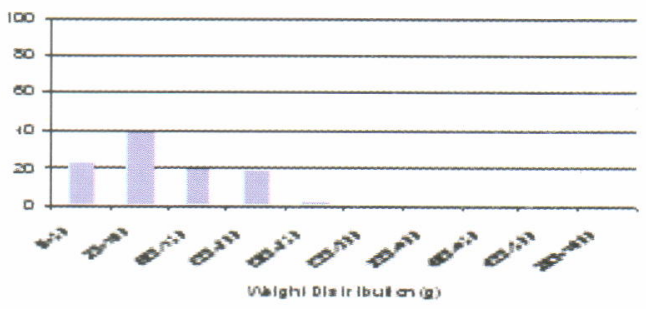

Figure 13.

Percentage of weight distribution of lobster sample, January to October 2009.

From data analysis it was found that the dominant size of lobster collected in January to October 2009 was in the stage of juvenile or can be categorized as seed with the monthly average of about $84 \%$ of the total catch, and the highest percentage occurred in January (94\%) (Figure 13). Seed abundance pattern is similar to the pattern of the lobster fishing season
(Figure 8), with the peak at the end of the year to the beginning of the following year. Further analysis shown that in the end of the year the juvenille stage lead tc decrease in contrast to larger size that $r \epsilon^{\prime}$ 'atively increase. Some management measures that lead to the optimum and sustainable yield in the South Coast of Yogyakarta needs to be proposed. 


\section{CONCLUSION}

The dominant size of lobster collected in January to October 2009 was in the stage of juvenile with the monthly average of about $84 \%$ of the total catch with individual weight of $30-100 \mathrm{~g}$. It was identified that lobster species consisted of sand lobster (Panulirus homarus), brown spiny lobster (P. penicillatus), pearl lobster ( $P$. ornatus), dark-green striped leg spiny lobster ( $P$. versicolor), painted spiny lobster ( $P$. longipes), grey-blue spotted legs ( $P$. polyphagus), and red-spanish lobster Scyllarides squammosus). The first two species contribute the most abundance group as reflected by the highest amount in the catch followed by P.ornatus. Lobster fishing season characterized by high production in the south coast of Yogyakarta occur at the end of the year to the beginning of the following year. Management measure leading to the optimum yield and sustainable lobster fisheries in the south coast of Yogyakarta include application of minimum legal size at the collector level that can be enforced through a district government regulation. A lobster growing out pilot project could be initiated by the collector in co-operation with the local government institution, such as District of Marine Affairs and Fisheries Services and other interested private sectors. An understanding of the importance of the lobster seed protection should be intensively informed in the fisher community. It is acknowledged that seed and juvenile size will get lower price. Intensive fishing activities of this stage will lead to the collapse of the fishery.

\section{ACKNOWLEDGMENTS}

This paper is part of the research results carried out in the framework of research collaboration between the Agency for Marine and Fisheries ResearchDirectorate General of Higher Education of the Ministry of National Education, Indonesia in the F. Y. 2009 , to whom the authors would like to express their gratitude.

\section{REFERENCES}

Anonymous. 2007. Fisheries Statistics of Indonesia. $134 \mathrm{pp}$.

Anonymous. 2008. Fisheries Statistics of Gunung Kidul District.

Anonymous. 2009. Life Cycle and Reproduction. http : //www.lobster.um. maine.edu/.

Aisyah, Badrudin, \& S. Triharyuni 2009. Lobster Seed Resources in the Sulth Coast of
Yogyakarta. AARD. MMAF. (Unpubslihed Report, in Indonesian with English Abstract). 25 pp.

Badrudin, I. G. Merta, A. Suman, T. Hariati, S. T. Hartati, I. S. Wahyuni, T. Ernawati, S. Bahar, \& A. Gunawan. 2005. Indeks kelimpahan stok sumber daya ikan di wilayah pengelolaan perikanan Samudera Hindia. Laporan Penelitian Balai Riset Perikanan Laut. (In Indonesia with English Abstract). $182 \mathrm{pp}$.

Chan, T. Y. 1998. Lobsters. FAO Species Identification Guide for Fishery Purposes, the Living Marine Resources of the Western Central Pacific. Vol. 2. FAO-UN. Rome. 1.,396 pp.

Chang, Yi-Jay, Chiu-Lu Sun, Yong Chen, Su-Zan Yeh, Wei-Chuan Chiang. 2007. Reproductive biology of the spiny lobster, Panulirus penicillatus, in the southern coastal waters off Taiwan. Marine Biology. 151: 553-564 pp.

Effendie, I. 2002. Biologi Perikanan. Yayasan Pustaka Nusatama. Yogyakarta. $97 \mathrm{pp}$.

FAO. 1998. Species Icientification Guide for Fishery Purposes, the Living Marine Resources of the Western Central Pacific. Vol. 2 Cephalopods, Crustaceans, Holothurians, and Sharks. 1,396 pp.

Herianti, I. 1997. Perikanan udang barong (Spiny Lobster) di perairan pantai Daerah Istimewa Yogyakarta. Prosiding Seminar Penerapan Teknologi Spesifik Lokasi dalam Rangka Menunjang Efisiensi Usaha Pertanian di Jawa Tengah dan Yogyakarta. Yogyakarta 26 Maret 1997. Balai Pengkajian Teknologi Pertanian. Ungaran. 209-215 pp.

Kanna, I. 2006. Lobster, penangkapan, pembesaran, permbenihan. Seri Budi Daya. Terbitan Kanisius $101 \mathrm{pp}$.

Lagler, K. F., J. E. Bardach, R. R. Miller, \& D. R. M. Passino. 1977. Ichthyology. John Willey ans Sons. Inc. New York-London-England. 506 pp.

-

Moosa, M. K. \& I. Aswandy. 1984. Udang Karang (Panulirus spp.) dari Perairan Indonesia. LONLIPI. Jakarta. $38 \mathrm{pp}$.

Nuraini, S. \& B. Sumiono. 2006. Parameter biologi udang barong di pantai selatan Pangandaran, Jawa Barat. Prosiding Seminar Nasional Perikanan. Universitas Gadjah Mada. 9 pp. 
Romimohtarto, Kasijan, \& S. Juwana. 1999. Biologi Laut, IImu Pengetahuan tentang Biota Laut. Pusat Penelitian dan Pengembangan Oseanologi. Lembaga IImu Pengetahuan Indonesia. Jakarta $527 \mathrm{pp}$.

Subani, W. 1981. Penelitian lingkungan hidup udang barong (spiny lobster), perikanan, dan pelestarian sumber daya di Pantai Selatan Bali. Bulletin Penelitian Perikanan. I: 361-386.

Subani, W., B. Sadhotomo, \& K. Surya. 1982 Penelitian tentang pertumbuhan dan beberapa parameter biologi udang pantung (Panulirus homarus) di perairan pantai selatan Bali. Laporan Penelitian Perikanan Laut. (Marine Fisheries Research Report). Badan Penelitian dan Pengembangan Pertanian. Departemen Pertanian. Jakarta. 24: 37-52.

Subani, W. 1983. Survai alat penangkapan udang barong di pantai selatan Bali. Laporan Penelitian Perikanan Laut. (Marine Fisheries Research Report). No.2.5 Tahun 1983. Balai Riset Perikanan Laut. Badan Penelitian dan Pengembangan Pertanian. Departemen Pertanian. Jakarta. 37-52.

Suman, A., M. Rijal, \& W. Subani. 1993. Status perikanan udang karang di perairan Pangandaran, Jawa Barat. Jurnal Penelitian Perikanan Laut. 81: $1-7$
Suman, A. \& W. Subani. 1993. Pengusahaan Sumber daya udang karang di perairan Aceh Barat. Jurnal Penelitian Perikanan Laut. 81: 84-90

Suman, A., W. Subani, \& P. Prahoro. 1994. Beberapa parameter biologi udang pantung (Panulirus homarus) di perairan Pangandaran, Jawa Barat. Jurnal Penelitian Perikanan Laut. 85: 1-8.

Smith, G. G. 1995. The World Market for Lobster. Globefish. Research Programme. 3,691 pp.

Suadi, R. Widaningroem, Soeparno, \& N. Probosunu 2001. Kajian sumber daya lobster di pantai selatan Daerah Istimewa Yogyakarta. Jurnal IImu-IImu Perairan dan Perikanan Indonesia, Edisi Khusus Crustacea. 1 (2): 33-42.

Wirosaputro, S. 1996. Jenis dan seks-rasio udang barong (Panulirus spp.) di kawasn Pantai Gunung Kidul, Yogyakarta. Jurnal Perikanan Universitas Gadjah Mada. Fakultas Pertanian. Universitas Gadjah Mada. 12-21.

Wahyuni, I. S., S. T. Hartati, \& W. Subani. 1994. Perikanan udang karang (spiny lobster) di perairan Kabupaten Tabanan, Bali. Jurnal Penelitian Perikanan Laut. 87: 84-90. 